\title{
Pluton emplacement in a releasing bend in a transpressive regime: the arrozal granite in the Paraíba do Sul shear belt, Rio de Janeiro
}

\author{
ALEXIS R. NUMMER ${ }^{1}$, RÔMULO MACHADO ${ }^{2}$ and NOLAN M. DEHLER ${ }^{3}$ \\ ${ }^{1}$ Universidade Federal Rural do Rio de Janeiro, Itaguaí, Km 47, 23851-970 Seropédica, RJ, Brasil \\ ${ }^{2}$ Universidade de São Paulo, Instituto de Geociências, Rua do Lago, 562, 05508-900 São Paulo, SP, Brasil \\ ${ }^{3}$ RH/UP - Universidade Petrobrás, Av. General Canabarro, 500, Maracanã, 20031-912 Rio de Janeiro, RJ, Brasil \\ Manuscript received on April 14, 2005; accepted for publication on May 3, 2006; \\ presented by ALCIDES N. SIAL
}

\begin{abstract}
The Arrozal Granite, situated in the southwestern region of the State of Rio de Janeiro, has a granitic to granodioritic composition. It contains a strong mylonitic foliation along its border, passing gradually to a well-developed magmatic foliation towards its center. Structural analysis indicates that the Arrozal Granite was emplaced along the Além-Paraíba Shear Zone in a dextral transpressive tectonic regime. A regional shift of the trend along this shear zone from NE-SW to $\mathrm{E}-\mathrm{W}$, observed in the area, is interpreted to be casually related to the creation of space for the emplacement of the granite. Our data indicate that releasing bends may have played an important role for space generation during the emplacement of the Arrozal Granite and other plutons.
\end{abstract}

Key words: releasing-bend, transpression, Arrozal Granite, emplacement.

\section{INTRODUCTION}

The importance of shear zones in the emplacement of granitoid plutons is well known, and for many syntectonic plutons have been related to transpressive deformation regimes (e.g. Hutton 1982, Hutton and Reavy 1992, McCaffrey 1992), pull-apart structures and spacegeneration flexures or releasing bends (e.g. Guineberteau et al. 1987, Hutton 1988a, b). In all these cases it is important to understand the internal fabric of the granitoids, as well as their relationship with the regional structure and the framework of the magmatic flow and solid-state deformation (e.g. Paterson et al. 1989 for review). In transpressive orogens, post-tectonic intrusions in the upper crust may be coeval with syn-tectonic plutons emplaced in the middle crust (D'Lemos et al. 1992).
The Além-Paraíba Shear Zone is one of the most important structures in the central part of the Paraíba do Sul Shear Belt. This tectonic structure has been classically regarded as a dextral shear zone developed in response to a transpressive regime which produced wide mylonitic zones (Ebert et al. 1991, 1993, Correa Neto et al. 1993, Machado and Endo 1993). Determination of stress directions from plagioclase fabrics has confirmed the kinematics of this deformation regime, suggesting that pure shear was more important than simple shear (Egydio-Silva and Mainprice 1999).

This paper focuses on the geometric and kinematic analysis of the Arrozal pluton and its host rocks. The pluton is one of the Neoproterozoic granites that crop out in the central part of the Paraíba do Sul Belt, in the southwestern region of the State of Rio de Janeiro.

Correspondence to: Rômulo Machado

E-mail: rmachado@usp.br 


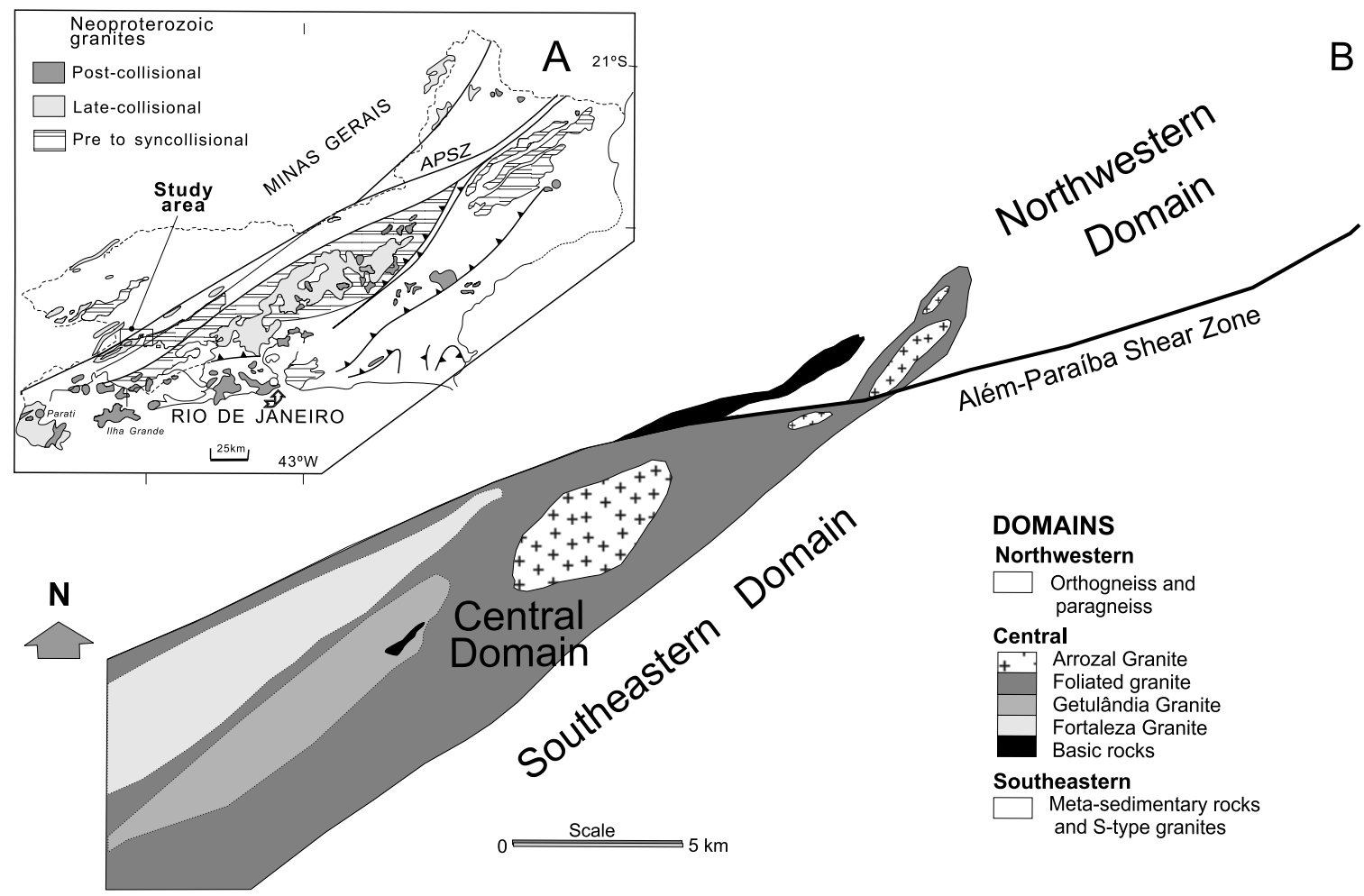

Fig. 1 - (A) Geological sketch map of the Neoproterozoic granites of the State of Rio de Janeiro (B) and Map of the Arrozal Granite.

\section{REGIONAL GEOLOGY}

Regional syntheses concerning the Neoproterozoic granite plutons of the Paraíba do Sul Belt, also called Ribeira Belt, in Rio de Janeiro State were published by Machado and Peloggia (1987), Machado and Demange (1994, 1998), Junho (1998), Heilbron et al. (2000, 2004). A considerable amount of work has focused on isolated plutons, mainly those in the vicinity of the cities of Rio de Janeiro, Petrópolis and Teresópolis, and concentrates on the petrography and geochemistry of these plutons. Only few accounts include detailed structural studies, geochronology and mineral chemistry.

$\mathrm{Rb} / \mathrm{Sr}$ and $\mathrm{U} / \mathrm{Pb}$ data for the pre-, syn- and postcollisional granitic magmatism of the belt indicate ages ranging from $634 \mathrm{Ma}$ to $490 \mathrm{Ma}$ (Figueiredo and Campos Neto 1993, Cordani et al. 1973, Machado et al. 1996b, Machado 1997, Heilbron et al. 2000, 2004), with the following sub-ranges: 590-570 Ma, 560-530 Ma and 520$450 \mathrm{Ma}$ (Figueiredo and Campos Neto 1993, Wiedemann 1993). These data suggest three phases of magmatism.
Furthermore, R. Machado (unpublished data) suggested older ages for the main groups of granite plutons, respectively: 650-620 Ma (pre-collisional), 600-590/570 Ma (collisional) and 560-530 Ma (late collisional).

Two magmatic arcs involving calc-alkaline, medium to high potassium and metaluminous to slightly peraluminous magmatism have been proposed for this area, the Rio Paraíba do Sul Arc with an ages between 650 to $600 \mathrm{Ma}$ (Machado and Demange 1998), and the Rio Doce Arc, with ages between 590 and 540 Ma (Figueiredo and Campos Neto 1993, Campos Neto and Figueiredo 1995, Wiedemann 1993).

\section{ChARACTERISTICS AND DisTRIBUTION OF THE GRANITOID PLUTONS}

Neoproterozoic granitic magmatism of the Paraíba do Sul belt in Rio de Janeiro State has been divided into three main groups: (i) pre to syn-collisional; (ii) late collisional; and (iii) post-collisional (Machado et al. 2000, Heilbron et al. 2000, 2004) (Fig. 1A). 
Pre- to syn-collisional batholiths are distinguished by their well-developed linear and foliated structures, which are aligned parallel to the regional trends. Granites with I-type and S-type affinities are the characteristic components of these batholiths. I-type granites have an expanded magmatic composition (granite/granodiorite and tonalite) and are comparable in volume to those of the S-type association. As suggested by Machado and Demange (1998), and Machado et al. (2000), the pre- to syn-collisional granites are comparable to I-type Cordilleran batholiths, based on petrological and geochemical studies. Towards the Atlantic coast, the I-type granites are associated with charnockite or rocks with similar mineral assemblages. S-type granites occur in the southernmost part of the area. They involve leucocratic rocks of granitic to granodioritic composition, containing mica-rich enclaves and muscovite, garnet, tourmaline and sillimanite.

The late-collisional granites are mainly distributed along the Além-Paraíba Shear Zone (APSZ, Figs. 1A, 1B). The Arrozal Granite (Fig. 1B) is an example of this group. These granites have an ellipsoidal shape and exhibit steep-dipping magmatic foliation sub-parallel to the mylonitic fabric of the shear zone. They are characterized by an inequigranular to porphyritic texture, a pink color, and their main composition is monzogranitic (Machado and Demange 1994). U/Pb ages on monazite yielded $535 \pm 1$ Ma to $528 \pm 1$ Ma for the Getulândia Granite (Machado et al. 1996a), supporting their correlation to the late-collisional granite group (see Fig. 1A).

The Arrozal Granite has petrographic and structural features similar to the Getulândia Granite. Charnockitic $(0.5$ to $3 \mathrm{~m})$ and dioritic $(0.3$ to $0.5 \mathrm{~km})$ enclaves are present in this granite. Their forms display evidence for heterogeneous magma mixing with granitic magma. The enclaves are round to ellipsoidal or irregular in shape and display transitional contacts with their host granite. Euhedral crystals of K-feldspar and plagioclase derived from the granite are found inside the charnockitic enclaves, indicating at least partial coexistence of the two magmas.

The post-collisional granites occur mainly in the southeastern part of the state (Fig. 1A). They are distributed along an E-W trend, suggesting that emplacement was not related with the regional structures of the older granites. The emplacement of these granites occurred during an extensional regime. Available $\mathrm{U} / \mathrm{Pb}$ and $\mathrm{Rb} / \mathrm{Sr}$ isotope data on the Mangaratiba and Sana plutons indicate comparable ages of $492 \pm 15 \mathrm{Ma}(\mathrm{U} / \mathrm{Pb}$, on titanite) and $488 \pm 3,6 \mathrm{Ma}(\mathrm{Rb} / \mathrm{Sr})$, respectively (Machado et al. 1996a, b).

\section{ARROZAL GRANITE (AG)}

The Arrozal Granite (AG) is an elongated body, with magmatic foliation in its central part and solid-state deformation at the border. The magmatic fabric includes alignment of K-feldspar and biotite. In general, textures are medium- to coarse-grained, inequigranular and porphyritic. Basic to intermediate enclaves occur locally. The composition of the AG is syeno- to monzogranitic and, subordinately, granodioritic. Biotite is the main mafic mineral, followed by hornblende. Muscovite, apatite, titanite, zircon, garnet and magnetite are the accessory minerals. Leucogranite, unrelated to the Arrozal pluton, with muscovite, tourmaline, garnet and sillimanite occur in the eastern (Passa Três region) and southern parts of this pluton.

\section{RESULTS AND DISCUSSION}

The area was divided into three structural domains: Northwestern (ND), Central (CD) and Southeastern (SD) (Fig. 2). An expressive high-angle ductile shear zone (Além-Paraíba Shear Zone - APSZ) appears at the contact between the northern and central domains (Fig. 2). There are also other important high-angle ductile shear zones that occur in the internal portion of the northern domain, which are sub-parallel to the SWNE regional trend (Fig. 2). Both shear zones display dextral movement and are considered to be transpressive structures associated with the formation of mylonites (Ebert et al. 1991, 1993, Correa Neto et al. 1993, Machado and Endo 1993).

Paleoproterozoic orthogneiss is the predominant rock-type in the northern domain. Granitic rocks are the most important components of this domain, whereas the southern domain is mainly composed by metasediments, with orthogneiss and granite as minor components. 


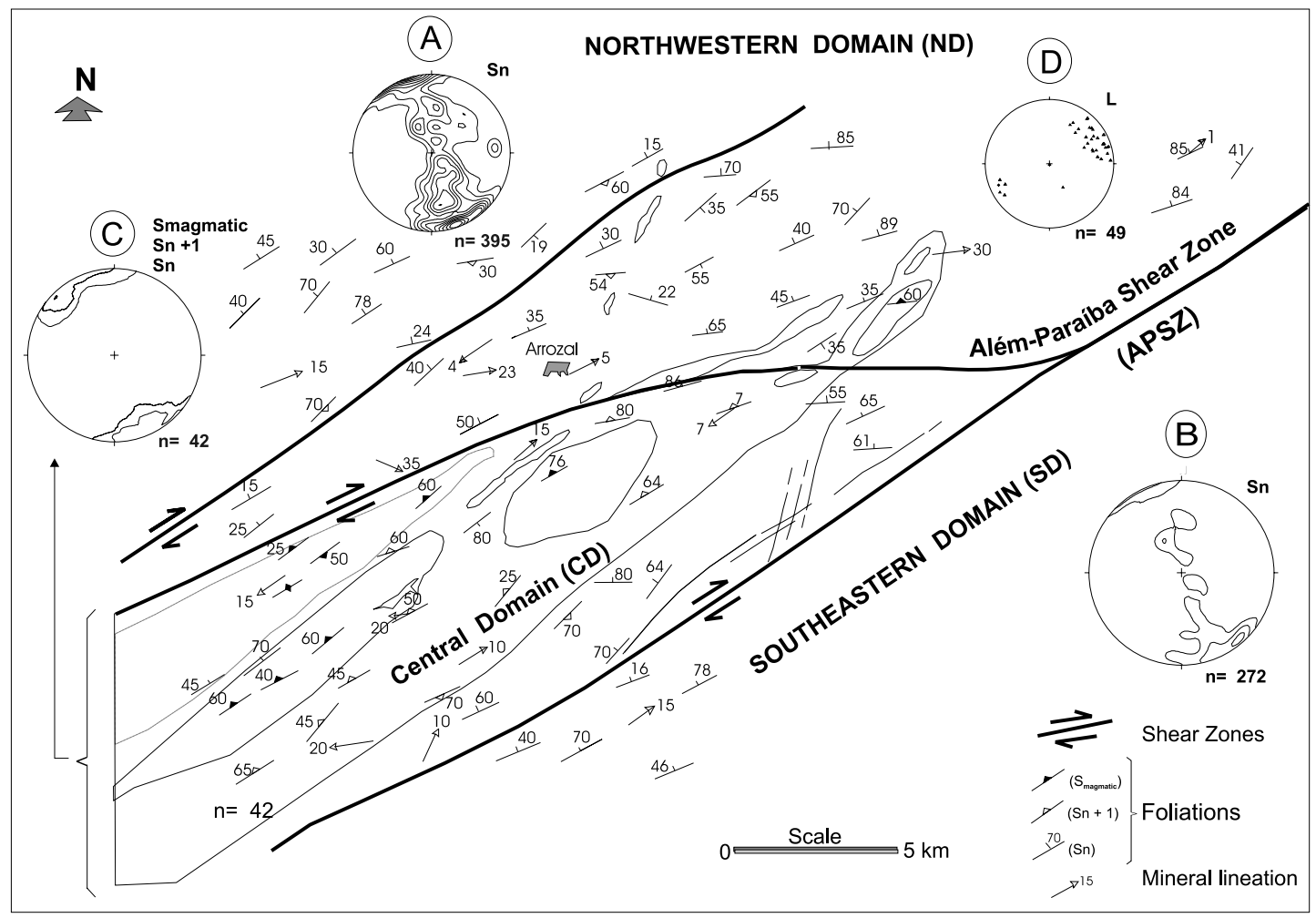

Fig. 2 - Structural map of the Arrozal Granite and its surroundings, southwestern region of the State of Rio de Janeiro, with stereographic plots (lower hemisphere projections) of three structural domains: (A) and (B) Sn foliation (gneissic banding), (C) magmatic foliation ( $S_{\text {magmatic }}$ ) and foliation in the solid-state (Sn+1) and (D) Mineral stretching lineation.

\section{NORTHWESTERn DOMAIN (ND)}

Two foliations were observed in orthogneiss of this domain, referred to as $\mathrm{Sn}$ and $\mathrm{Sn}+1$.

The Sn foliation corresponds in several places to a sub horizontal gneissic banding in the orthogneiss. Tight to isoclinal folds and rootless structures with thickened hinges and thinned limbs were observed along this banding. These features suggest transposition of older structures during the deformation related to the generation of the banding, characterized by discontinuous, alternating centimetric to decimetric bands of quartz-feldspar and biotite-amphibole, respectively.

In this domain, the $\mathrm{Sn}$ foliation generally strikes $\mathrm{N} 75^{\circ} \mathrm{E}$, with sub-vertical to moderate dip towards NW. The Sn distribution in the stereogram appears to show the influence of a younger folding phase with an average axis plunging $\mathrm{S} 70^{\circ} \mathrm{W} / 10^{\circ}$ (Fig. 2A). The Sn foliation surfaces display an ENE-trending and contain a biotite lineation with gentle plunges to NE or SW (Fig. 2D).

The $\mathrm{Sn}+1$ foliation is generally discontinuous and poorly developed except near the shear zones where it is well developed, being mainly parallel to the Sn banding.

\section{SOUTHEASTERn DOMAIN (SD)}

Metasedimentary rocks and S-type granitoids are the main components of this domain. The average trend of the main tectonic foliation $\mathrm{Sn}$ is $\mathrm{N} 69^{\circ} \mathrm{E}$, with moderate to sub-vertical dips to NW and SE (Fig. 2B). In this domain a well-developed stretching lineation plunging slightly to NNE occurs, defined by sillimanite, biotite and feldspar, and contained in the Sn foliation plane.

\section{Central Domain (CD)}

The Arrozal Granite (AG) is included in this domain. Two foliations were observed in the CD: a magmatic one 
and another interpreted to be generated by deformation in the solid-state. These two foliations are sub-parallel and sub-vertical with ENE-WSW trend, containing a maximum at $\mathrm{N} 45^{\circ} \mathrm{E} / 80^{\circ} \mathrm{SE}$, as shown in Figure $2 \mathrm{C}$.

The magmatic foliation is observed in the northern part of the central domain, where the pluton apparently escaped solid-state deformation superimposed by APSZ. According to the features shown on the structural map and corresponding diagrams (Fig. 2) the general NE trend is deflected to ENE near the Além-Paraíba Shear Zone.

The mineral stretching lineations plunge gently to ENE, or to WSW (Fig. 2D). The geometric relation between the foliation orientation and the stretching lineation in the ND (see Figs. 2A and 2D) is compatible with a predominance of transcurrent movements. The same type of movement is also inferred for the $\mathrm{CD}$ and $\mathrm{SD}$, based on the relation between these two structures.

A geometric analysis of the three structural domains indicates a very similar framework from the ND to the SD (Figs. 2A and 2B). However, only the first domain shows a continuous girdle in the stereoplot, suggesting the existence of regional folds with NE-SW axial surfaces and axes plunging gently to $\mathrm{SW}$, as confirmed by field observations. The $\mathrm{CD}$ shows a slightly different structural trend, in which the foliation displays a clockwise change in direction of about $30^{\circ}$ in the northern part of the domain (Fig. 2).

The geological framework and the tectonic model for the emplacement of the Arrozal Pluton are shown in Figure 3.

Figure 3A shows the regional pattern of the AlémParaíba Shear Zone. Figure 3B sketches the relationship between the main orientation of magmatic foliation in the Arrozal pluton and the orientation of the local trend of the Além-Paraíba Shear Zone. Figure 3C shows a NW-SE cross-section across the CD (for location, see Fig. 2). The steep dips of the Arrozal pluton and shear zones are supported by gravimetric data available for the region (A.R. Nummer, unpublished data). The horizontal trace of the high-angle dextral Além-Paraíba Shear Zone displays significant changes in its regional trend, varying from $\mathrm{N} 45^{\circ} \mathrm{E}$ to $\mathrm{N} 70^{\circ} \mathrm{E}$ in its southern segment (Fig. 1B). The dispersion of stretching lineations (Fig. 2D) in the stereogram is compatible with

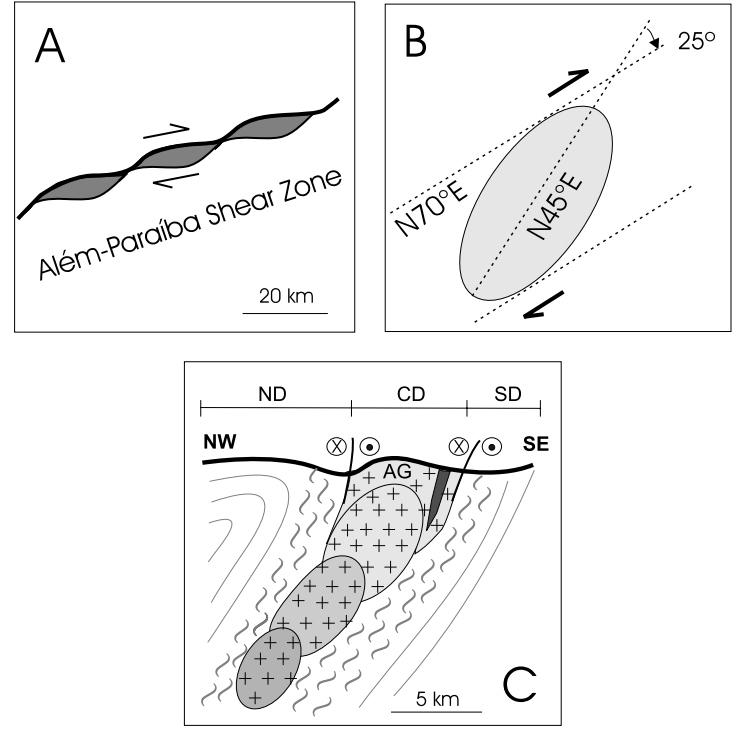

Fig. 3 - Simplified sketch of the Além-Paraíba Shear Zone (APSZ): A) Model of displacement along the APSZ and creation of transtensional spaces; B) Geometric relation between the APSZ and probable orientation of magmatic foliation during the emplacement of the $\mathrm{Ar}$ rozal Granite; C) Schematic NW-SE geological section cross-cutting the Arrozal Granite.

this change of foliation trend. We argue that a releasing bend associated with the curved trace of this shear zone created transtensional domains, providing space for the emplacement of granitic magmas (Figs. 3A and 3C), as reported in several cases of syntectonic plutons associated with transpressional regime shear zones (e.g. Hutton 1982, 1988b, Guineberteau et al. 1987, Hutton and Reavy 1992). The dextral displacement observed in the northern part of the APSZ was possibly synchronous with the emplacement of granitic magma (Fig. 2, Central Domain).

The Arrozal Granite displays a magmatic foliation preserved in parts of low strain, and a weak solid-state subsequent deformation, mostly in the central part of the pluton (Central Domain: Fig. 2). On the other hand, protomylonite and mylonite, which were developed by the dextral displacement of the Além-Paraíba Shear Zone, are found along the intrusion margins.

\section{FINAL REMARKS}

The structural data presented and discussed in this paper are compatible with the development of a releasing 
bend in the southwestern segment of the Além-Paraíba Shear Zone. If correct, this model implies that the emplacement of the Arrozal Granite is related to the dextral movement of the Além-Paraíba Shear Zone. U/Pb ages in monazite of $535 \pm 1 \mathrm{Ma}$ and $528 \pm 1 \mathrm{Ma}$ (Machado et al. 1996a) were obtained for the Getulândia Granite, which is considered to be contemporaneous to the Arrozal Granite (Arrozal Suite of A.R. Nummer, unpublished data). This age is related to the cooling of the syntectonic granite, and it appears to be also the age of emplacement of the Arrozal Granite, which is related to the tectonic phase $\mathrm{Dn}+1$.

The development of a mylonitic foliation at a small angle with the trend of the magmatic foliation of the Arrozal Granite is compatible with the development of a magmatic fabric within a transtensional environment at a local scale. Crystallization possibly occurred coeval with the deformation related to the dextral displacement of the Além-Paraíba Shear Zone (regional scale). In addition, the granitic rocks exhibit an increasing deformation towards this structure, suggesting that solid-state deformation occurred after the magmatic crystallization fabrics. Therefore, we argue for a model of releasing bends in a tranpressive regime associated with the sinuous trace of this steep-dipping dextral shear zone. Such kinematic conditions may have developed space favorable for the ascension and emplacement of granitic magmas.

The gravimetric modeling (A.R. Nummer, unpublished data) of the Arrozal Granite shows that the emplacement of granitic magma occurred along steeply NW dipping shear zones (see Fig. 3C) and that the attitude of the foliation of the Northwestern Domain changes from horizontal to subvertical near the boundary of the shear zone.

\section{ACKNOWLEDGMENTS}

The authors express their thanks to Thelma Samara for her help in drafting the figures; to Fundação de Amparo à Pesquisa do Estado de São Paulo (FAPESP, Proc. 98/00912-8) for supporting fieldwork, and to Rogério Noal Monteiro, Wilson Teixeira and Ian McReath for an early review of this paper. RM gratefully acknowledges the Conselho Nacional de Desenvolvimento Científico e Tecnológico (CNPq) research fellowship (30.0423/ 82-9).

\section{RESUMO}

O Granito Arrozal ocorre na porção sudoeste do Estado do Rio de Janeiro e associa-se à Zona de Cisalhamento de AlémParaíba. Possui composição granítica a granodiorítica e exibe predomínio de estruturas magmáticas na parte central, e estruturas de alto strain (miloníticas) nas bordas. Os dados estruturais sugerem colocação em segmentos extensionais (releasing bends) associados a uma tectônica transcorrente destral, sob regime transpressivo. A forte mudança do trend estrutural desta zona de cisalhamento na região, passando de NE-SW para próximo de E-W, criou condições para geração de espaços que favoreceram a colocação do Granito Arrozal, além de outros granitos associados à referida zona.

Palavras-chave: "zonas de alívio", transpressão, Granito Arrozal, colocação.

\section{REFERENCES}

Campos Neto MC and Figueiredo MCH. 1995. The Rio Doce orogeny, Southeastern Brazil. J South Am Earth Sci 8: 143-162.

Cordani UG, Delhal J And Ledent D. 1973. Orogénèses superposées dans le Pré-Cambrian du Brésil SudOriental (États de Rio de Janeiro et de Minas Gerais). Rev Bras Geoc 3: 1-22.

Correa neto AV, Dayan H, Valença JG And RAPHAEL CA. 1993. Geologia e estrutura da zona de cisalhamento do Rio Paraíba do Sul entre Três Rios (RJ) e Sapucaia (RJ). Atas III Simp Geol Sudeste, Rio de Janeiro, RJ, Brasil, p. 194-200.

D'Lemos RSD, Brown M AND Strachan RA. 1992. Granite magma generation, ascent and emplacement within a transpressional orogen. J Geol Soc London 149: 487-490.

EBERT HD, Hasui Y AND Costa JBS. 1991. O caráter transpressivo do Cinturão de Cisalhamento Rio Paraíba do Sul. Bol II Simp Nac Est Tect, Rio Claro, SP, Brasil, p. $139-141$.

Ebert HD, Hasui Y, Santoro G, Almeida SH and Costa JBS. 1993. Arcabouço estrutural e tectônica transpressiva das faixas móveis da borda sul e sudeste do cráton do São Francisco e da sintaxe de Guaxupé. Bol Res IV Simp Nac Est Tect, Belo Horizonte, MG, Brasil, p. $166-171$.

Egydio-Silva M ANd MaInPRICE D. 1999. Determination of stress directions from plagioclase fabrics in hig grade deformed rocks (Além Paraíba shear zone, Ribeira fold belt, southeastern Brazil). J Struct Geol 21: 1751-1771. 
Figueiredo MCH And Campos Neto MC. 1993. Geochemistry of the Rio Doce magmatic arc, Southeastern Brazil. An Acad Bras Cienc 65 (Suppl 1): 63-81.

Guineberteau B, Bouchez JL and Vigneresse JL. 1987. The Mortagne Granite Pluton (France) emplaced by pull-apart along a shear zone: structural and gravimetric arguments and regional implication. Geol Soc Amer Bull 99: 763-770.

Heilbron M, Moriak Wu, Valeriano CM, Milani EJ, ALMEIDA J AND TUPINAMBÁ M. 2000. From collision to extension: the roods of the sourheastern continental margin of Brazil. In: MOHRIAK WU AND TALWANI M (Eds), Atlantic rifts and continental margins. Washington DC AGU, Geophysical Monograph 115: 1-32.

Heilbron M, Pedrosa Soares AC, Campos Neto MC, Silva LC, Trouw RAJ and Janasi VA. 2004. Província Mantiqueira. In: Mantesso-Neto V, BARTORELli A, CARneiro CDR ANd BRito Neves BB (Eds), Geologia do Continente Sul-Americano: Evolução da Obra de Fernando Flávio Marques de Almeida Cap XIII, Beca, p. 203-235.

HUtTON DHW. 1982. A tectonic model for the emplacement of the Main Donegal granite, NW Ireland. J Geol Soc London 139: 61-631.

HutTon DHW. 1988a. Granite emplacement mechanism and tectonic controls: Inferences from deformation studies. Royal Soc Ed Trans 79: 245-255.

HutTon DHW. 1988b. Igneous emplacement in a shear zone termination: the biotite granite at Strontian, Scotland. Geol Soc Amer Bull 100: 1392-1399.

HutTon DHW AND REAVy RJ. 1992. Strike-slip tectonics and granites petrogenesis. Tectonics 11: 960-967.

JunHo MCB. 1998. Rochas granitóides do estado do Rio de Janeiro. In: FonseCA MJG (Ed), Mapa geológico do Estado do Rio de Janeiro, escala 1:400.000. Rio de Janeiro, DNPM/MME, $141 \mathrm{p}$.

Machado N, Valladares C, Heilbron ML and VaLERIANO CM. 1996a. U-Pb geochronology of the central Ribeira Belt (Brazil) and implications for the evolution of the Brazilian Orogeny. Prec Res 79: 347-361.

MACHADO R. 1997. Litogeoquímica e tectônica dos granitóides neoproterozóicos do Cinturão Paraíba do Sul no Estado do Rio de Janeiro. Tese de Livre-Docência, Instituto de Geociências, Universidade de São Paulo, SP, Brasil, 215 p.
Machado R And Demange M. 1994. Classificação estrutural e tectônica dos granitóides Neoproterozóicos do Cinturão Paraíba do Sul no Estado do Rio de Janeiro. Bol Inst Geoc da USP, Série Cient 25: 81-96.

Machado R And Demange M. 1998. Caracterização geoquímica e tectônica dos granitóides pré-colisionais neoproterozóicos do cinturão Paraíba do Sul no Estado do Rio de Janeiro. In: CoNCEIÇÃo H (Ed), Contribuição ao estudo dos granitos e rochas correlatas. SBG/Núcleo Bahia-Sergipe, Publicação Especial 5: 21-39.

MAchado R AND ENDo I. 1993. O Cinturão de Cisalhamento Atlântico: um exemplo de tectônica transpressional neoproterozóica. Bol Res IV Simp Nac Est Tect, Belo Horizonte, MG, Brasil, p. 188-191.

Machado R and Pellogia AUG. 1987. Mapa de distribuição das rochas granitóides do Estado do Rio de Janeiro: uma avaliação preliminar das informações disponíveis. Atas IV Simp Reg Geol, Rio Claro, SP, Brasil 1: 93-96.

Machado R, Demange M and Viallete Y. 1996b. Idades geocronológicas $\mathrm{Rb} / \mathrm{Sr}$ da granitogênese brasiliana no segmento setentrional da faixa Ribeira, Estado do Rio de Janeiro. Bol Res XXXIX Congr Bras Geol, Salvador, BA, Brasil 1: 38-40.

Machado R, Demange M, McReath I and Moutte J. 2000. Crustal zoning of neoproterozoic pre-collisional granitoids in the Paraíba do Sul belt, Rio de Janeiro, Brazil. Rev Bras Geoc 1: 70-73.

MCCAFFREY KJW. 1992. Igneous emplacement in a transpressive shear zones: Ox Montains igneous complex. J Geol Soc London 149: 221-235.

PATERSON SR, Vernon RH AND TOBISCH OT. 1989. A review of criteria for the identification of magmatic and tectonic foliations in granitoids. J Struct Geol 11: 349363.

Wiedemann CM. 1993. The evolution of the Paleozoic, lateto post-collisional magmatic arc of the coastal mobile belt, in the State of Espírito Santo, eastern Brazil. An Acad Bras Cienc 65 (Suppl 1): 163-181. 